\begin{tabular}{c} 
Volume and Issues Obtainable at Center for Sustainability Research and Consultancy \\
Journal of Accounting and Finance in Emerging Economies \\
ISSN: 2519-0318 ISSN (E) 2518-8488 \\
Volume 6: Issue 4 December 2020 \\
CSRC \\
Journal homepage: $\underline{\text { www.publishing.globalcsrc.org/jafee }}$ \\
\hline
\end{tabular}

\title{
Openness and Inflation Volatility: A Case Study SAARC Country
}

\begin{tabular}{|c|c|}
\hline \multirow{2}{*}{\multicolumn{2}{|c|}{ 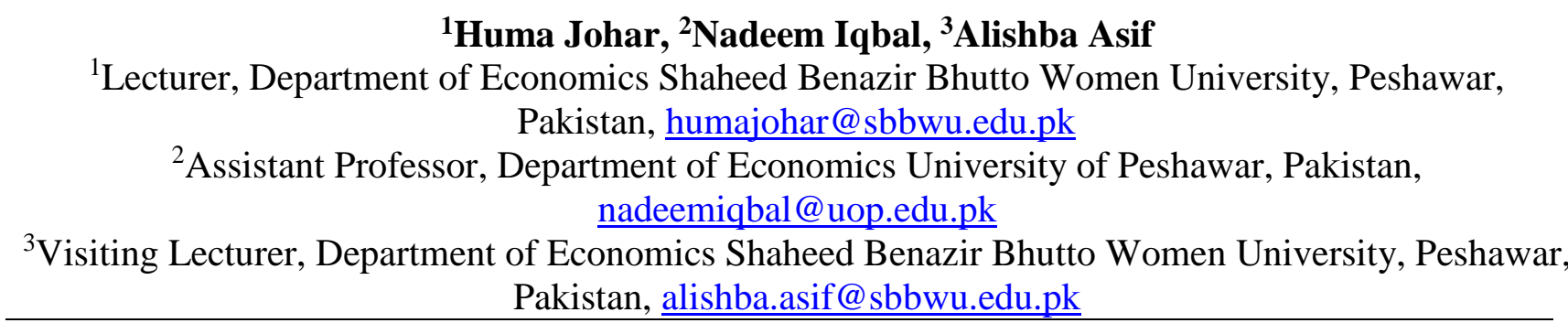 }} \\
\hline & \\
\hline AR' & \\
\hline $\begin{array}{l}\text { History: } \\
\text { Revised form } \\
2020 \\
\text { Available On } \\
020\end{array}$ & $\begin{array}{l}\text { objective of this research paper is to che } \\
\text { ness on inflation volatility. The time period } r \\
\text { by utilizing Panel data for SAARC coun } \\
\text { bles are used to calculate openness by } u\end{array}$ \\
\hline $\begin{array}{l}\text { Keywords: } \\
\text { Openness, } S \\
\text { Volatility, } G\end{array}$ & ol. \\
\hline & 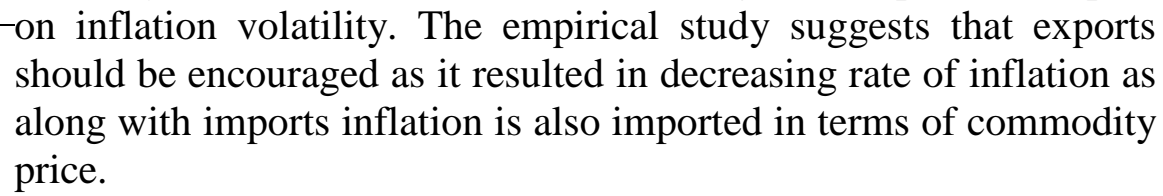 \\
\hline
\end{tabular}

(C) 2020 The authors, under a Creative Commons AttributionNonCommercial 4.0

Corresponding author's email address: humajohar@sbbwu.edu.pk

Recommended citation: Johar, H., Iqbal, N. \& Asif, A. (2020). Openness and Inflation Volatility: A Case Study SAARC Country. Journal of Accounting and Finance in Emerging Economies, 6(4), 1051-1058

\section{Introduction}

The rapid increase in world economic integration in the recent decades initiated arguments on the impact of trade openness on inflation volatility. One of the propositions prevailing is that greater openness tends to decline inflation rate. Economic liberalization and openness raised in 1990's, then countries started to integrate in order to increase their respective trade (Mukhtar 2008). Institutions like the World Bank, International Monetary Fund (IMF), and the Organization of Economic Co-operation and Development (OECD) claim that openness generates positive effects on economic growth which stabilizes inflation volatility (Jain and Singh 2009).

The decade of 1990's is remembered as era in which inflation around the world came under control. According to IMF, average inflation in industrialized countries comes down to $0.8 \%$ at the end of 1999 which was previously 4.9\% between 1982 and 1991. Also 1990's is considered as globalization decade, where trade of goods as percentage of GDP raises to $28.3 \%$ which was $21.2 \%$ in 1988 (Alfaro, 2005). 
In 1990's, countries which were highly open to international trade, particularly small countries adopted the policy of inflation targeting which resulted, in a major decline in inflation rates for both developed and developing countries (Thomas 2012).

Formation of trading blocks and regional trade agreements (RTA'S) is alternative best option. Countries move towards the creation of regional trade agreements. Moreover, another reason for economic integration is economies of scale because small nation cannot utilize its production capacity due to smaller market domestically. To achieve these advantages, South Asian Association for Regional Cooperation (SAARC) which includes eight countries was formed in December, 1985. However, due to precautious behavior of member nations the process of integration was very slow (Bhattarai 2014). Increasing step towards integration, SAARC countries first signed South Asian Preferential Trading Agreement (SAPTA) in April 1993 under which trade concession is allotted to member nation for specific list of goods. Secondly they singed South Asian Free Trade Area (SAFTA) in 2004 with objective to achieve free trade area by end of 2063 (Rizwan-ul-Hassan 2015). The objective of the study is to analyze the effects of openness on inflation volatility by utilizing cross-sectional correlation and temporal variation in the data. Also to check the potential endogeneity of openness by using lagged values of openness and population size as instrument in estimating dynamic panel model.

\section{Literature Review}

Romer (1991) put forward the relation between openness and inflation volatility. His explanation of the relation was based on unanticipated monetary policy. He concluded that unanticipated monetary policy lead to high inflation rate when there is imperfect competition and excessive burden of taxation. The result will be sub optimal level of output if monetary policy is used to effect output because policy will be to create surprise inflation but wage setters expectation and price policy cannot be the same which results in high inflation and natural rate of output (Kyland and Prescot 1977). If a country is keen on adopting unanticipated monetary policy, it will expand less and hence inflation will be on average low because unanticipated monetary policy causes real exchange rate depreciation which will harm more if the degree of openness is high.

Lane (1997) use panel data estimation to investigate the negative effect of openness on inflation volatility. He proposes that the negative relation can be stronger with the inclusion of time specific effects along with central bank independency. By giving conventional explanation to the results, he proposed that there is less benefit attached to surprise inflation in open economies because the terms of trade deterioration is limited. As only countries which are big enough to affect international market prices have more flexible exchange terms. Terra (1998) questioned Romer's empirical findings and estimates her own regression on sample of 20 countries with dividing them were into 4 groups according to indebtness level. The countries were further divided into severely, moderated and less debted countries with inclusion of pre-debt crisis and debt crisis. The finding shows that for severely indebted countries in Latin America there exist negative relation between openness and inflation but for moderately and less debted countries the negative relation does not hold. Also during 1970's and early 1980 's, when countries were decreasing their debt burden and do not face any issue relating to balance of payment the negative link between inflation and openness comes out to be weak but the negative relation become strong during debt.

Romer (1998) replies back to Terra's (1998) articles to prove his points. His study showed that severely indebted countries and moderately indebted countries both show negative relationship of openness and inflation and only for high income country the relation does not exist. His study also pointed that during borrowing period a country can run in trade deficit rather than surplus. Less open economy has more appreciated currency value as share of trade surplus and hence lower will be the budgetary pressure and low inflation. The relationship between openness and inflation volatility is even negative when countries are borrowing and more negative when they are indebted. Also his study shows that there is no evidence given by Terra (1998) those countries which are highly indebted shows larger trade surpluses. 
Ashra (2002) gives a different approach on the relationship between openness and Inflation by defining openness as total trade/GDP ratio, imports/GDP ratio and exports/GDP ratio, in different panel models, for the 15 countries. Correlation outputs shows that impact of the openness on inflation is found diverse when trade/GDP ratio is taken as the proxy variable of openness. Hence the effect of openness on inflation volatility depends on the proxy variable being used for openness and the variables exports/GDP and imports/GDP shows significant affects on inflation in opposite directions.

Jin (2006) examined the relation between openness, inflation and growth for South Korea by using autoregressive model and impulse response function. The results of impulse response function indicate significant response of openness on inflation and output growth. Further results show negative short run effect of openness on inflation and growth. The negative relation exists because of shrinkage of domestic investment when the competition increases in the international market and the effects will be large if in any case the inflows increases. The domestic economy will suffer when the financial market are not strong to compete in international market as happened in Korean financial crises (1997). Evans (2012) uses a two country OlG (overlapping generations) model in which each country produces each good in one period which last for only two periods. The estimated results shows that their exist a positive relation between Openness and inflation because of the fact that international consumer shows some degree of inelasticity in their preferences towards home products. This increases the prices of exports while the import prices remain same. The monetary authority take the decisions of applying consumption tax costs of inflation to balances the increases money growth that resulted from open economy.

Auer and Mehrotra (2014) worked on globalization and its impact on cross border prices for Asia and Pacific region. The increasing integration led to higher movement of prices internationally. For Asia and Pacific region the trade affects the domestic prices of trading countries because they are exposed to cross border demand and supply shocks and volatility of inflation rate increases domestically. Darici (2016) checked the effect of openness on inflation by taking cross sectional time series data for selected 11 developing countries from 1980-2006 and using fixed and random effect model. Estimation results show that exchange rate, openness to foreign trade and foreign direct investment variables have statistically significant and positive effects on inflation. Further finding shows that increase in per capita GDP, is also statistically significant and has positive effect on inflation.

\section{Theoretical Framework}

In this section the possible channel is trace out through which openness link with inflation volatility. The possible channels are:

Openness can increase instability if trade is majorly based on primary commodities as in case of many developing countries, openness causes greater exposure to most volatile international market. Moreover openness increases vulnerability to exchange rate fluctuations; however this will mainly depend on exchange rate regime. On the other hand, there are several linkages through which openness can reduces inflation volatility. Firstly, openness can affect inflation volatility through structure of consumption. When there is increase in income, it shifts the consumption level from low value added agriculture products towards manufactured goods. Developing countries usually lack capacity in supply of some consumer goods but to re-structure consumption in favor of high value added product they can compensate by importing these goods. This degree of substitution in consumption will depend on openness to trade. Also the terms of trade volatility for manufactured goods are $1 / 3^{\text {rd }}$ than aggregate terms of trade volatility (Baxter and Kouparitsas (2000). The change in structure of consumption will results in stabilize the consumer price volatility through flexibility in the supply resulted from trade. Openness resulted in larger reduction of inflation volatility through improved market access or tariff reduction and rapid exposure to international market. 


\section{Econometric Model}

The following model is used to measure inflation volatility.

$V I N F=\operatorname{Ln}[1+\operatorname{sd}(I N F)]$

Where

VINF= Inflation volatility

$\mathrm{sd}=$ Standard deviation

Inf = Inflation measure as growth in the price index over last year taken in decimal form

Log transformation is used to press down very large values which results in hyperinflation time period. Log of one plus standard deviation of inflation is used to avoid the mention situation.

To estimate the effect of openness on inflation volatility we use the following model (Bowdler and Malik 2017). The equation is taken in log form to make it normally distributed.

$V I N F_{\text {it }}=a+\beta V I N F_{\text {it }-1}+\not O P E N_{\text {it }}+X_{\text {it }}+\eta_{\text {it }}+\varepsilon_{\text {it }}$

To calculate openness 4 proxy variables are taken which include trade to GDP ratio, Export to GDP ratio, Import to GDP ratio and KOF index of globalization one by one in the above equation

Where

OPEN = Natural log of import relative to GDP

$\mathrm{X}_{\mathrm{it}}=$ Set of variables which include Population size, Exchange rate regime, External Debt to GDP ratio, Government spending, Money supply, Lag Population size and lag Openness

$\mathrm{i}=\mathrm{it}$ denotes individual country

$\mathrm{t}=$ time period

$\eta \mathrm{i}=$ country fixed effect

$\varepsilon_{\mathrm{it}}=$ error term

The lagged variable of inflation volatility in equation is used to control persistence in inflation volatility (act as a proxy also for variable effecting volatility at this stage).

To exclude the time invariant fixed effects take first difference of equation (2) and obtain $\triangle V I N F_{\text {it }}=\beta \Delta V I N F_{\text {it }-1}+\gamma \Delta O P E N_{\text {it }}+\Delta X_{i t}+\Delta \varepsilon_{\text {it }}$

By applying least square to equation 3 can cause problems. The error term is co-related with the lagged dependent variable (VINFit-1) as both include $\mathrm{e}_{i t-1}$. Also reverse causality can occur if in any case inflation act as a hindrance to trade than OPEN can endogenously determined. The impact of openness on inflation in such case is enlarged than normal.

To abolish the problem of reverse causality and error term correlation with lagged dependent variable Arellano and Bond (1991) suggested a Generalized Method of Moment technique. But the problem with GMM method is that it can lead to finite sample biases because lagged level of variables can be poor instruments for equation 2 in presence of high time series persistence and short panels.

An alternative approach suggested by Arellano and Bover (1995) is System-GMM estimator which uses lagged differences of each variable an instrument in estimating the relation in equation 2 and combine this with Differenced GMM estimates of equation 3. External instrument i-e, lagged values of log population size is used in implementing System GMM estimator because past population size helps to predict the evolution in openness and hence efficiency of GMM estimator increases. The period of analysis is from 1990 to 2018.

\section{Results}

To check the stationarity of data Levin-Lin-Chu unit root test is applied. The results of Levin-Lin-Chu test are given in table 1:

Table 1: Results of Unit Root Test

\begin{tabular}{|l|c|c|}
\hline \multicolumn{1}{|c|}{ Variables } & Level & $1^{\text {st }}$ difference \\
\hline IV & 0.4969 & 0.000 \\
\hline lagIV & 0.4969 & 0.000 \\
\hline IEGCR & 0.9454 & 0.000 \\
\hline LagIEGCR & 0.9754 & 0.000 \\
\hline
\end{tabular}




\begin{tabular}{|l|c|c|}
\hline POP & 0.000 & $\ldots \ldots$ \\
\hline LagPOP & 0.000 & $\ldots \ldots$ \\
\hline MS & 1.000 & 0.000 \\
\hline ERR & 0.1664 & 0.000 \\
\hline GSCR & 0.0714 & 0.000 \\
\hline EDGCR & 0.1602 & 0.000 \\
\hline KOF & 1.000 & 0.000 \\
\hline IGCR & 0.9699 & 0.000 \\
\hline LagIGCR & 0.0444 & $\ldots \ldots$ \\
\hline EGCR & 0.2574 & 0.000 \\
\hline LagEGCR & 0.0734 & 0.000 \\
\hline
\end{tabular}

Nullhypothesis $\mathrm{H}_{0}: \rho=0$ Alternative hypothesis $\mathrm{H}_{1}: \rho<0$. IV= inflation volatility. $\mathrm{POP}=\mathrm{Population}$ size MS=Money supply LagIV=lag inflation volatility GSCR=Government size EDGCR=External debt IEGCR=Trade/GDP ratio. Lag IEGCR=Trade/GDP ratio. ERR=Exchange Rate Regime. Lag POP=lag population size..IGCR=Import/GDP ratio. $\mathrm{LagIGCR}=\mathrm{Import} / \mathrm{GDP}$ ratio. EGCR=Export/GDP ratio. Lag $\mathrm{EGCR}=\mathrm{Export} / \mathrm{GDP}$ ratio.

In table 2 the basic empirical results are presented. Each model is calculated with different proxy of Openness which includes trade/Gdp, Import/GDP, Export/GDP and KOF/GDP ratio as proxy for Openness respectively. The estimated results are contradicted when the proxy variable is change. Column one shows estimation for model one. The R-squared is 0.75 . Trade/GDP ratio is taken as proxy for Openness. The coefficient of trade/GDP is positive and significant. This shows that increase in Openness results in $.25 \%$ increase in inflation volatility of a country. The reason is that there exist 'beggar-thy neighbor policy' in economic theory according to which country can share their cost of inflation with the trading countries and at the same time the benefit remain with the creating country. Similarly inflation is imported in the form of prices of raw material. Lag inflation volatility shows significant positive impact on inflation volatility, because past inflation inertia affects current inflation. Ajaz, Nain and Kamaiah (2016) result supported the positive impact of lagged inflation volatility on current inflation. Population size has negative and significant relation with inflation volatility. The findings are in accordance with Agarwal and Narayanan (2003) with significant negative impact on inflation volatility. Money supply has positive and significant relation with inflation volatility. According to Friedman's theory of money, inflation is always a monetary phenomenon. Samimmi et al (2012) find same significant positive results. Government spending has positive and significant effect on inflation volatility. Businesses increase their prices today if there is expected real wage path even if previously they were unable to increase the prices. This will generate a shift in expected inflation, which leads to a shift in household consumption towards the present. In an open economy the monetary authorities does not hold strong control on inflation and will resulted in higher inflation. Dupor and li (2014) also find positive effect of money supply on inflation volatility.

Column 2 shows import to GDP ratio as proxy R-squared value of $0.18 \%$ which shows the insignificancy of the model. Import to GDP ratio has positive but insignificant impact of Openness on Inflation Volatility.

Column 3 shows model 3 with R-squared value (0.79). Model 3 includes Export/GDP ratio as a proxy for Openness that increase in Openness results in a decreasing Inflation volatility with a smaller impact. Gosh (2014) results are supporting the negative results. External debt to GDP ratio has significant positive impact on inflation volatility.

Column 4 shows significant negative effect of KOF/GDP impact on Inflation Volatility. The finding shows that an increase in KOF index will results in a decrease of Inflation volatility. KOF index include economic, political and social globalization. Samimi et al (2012) also finds significant negative relation between KOF index and Inflation volatility. Money supply has negative and significant effect on 
inflation volatility which contradicted the literature. Population has insignificantly positive effect on inflation volatility while lagged population also shows insignificantly positive relation. Government spending shows significant positive impact on inflation volatility.

Table 2: Dependent Variable: Inflation Volatility

\begin{tabular}{|c|c|c|c|c|}
\hline $\begin{array}{c}\text { Independent } \\
\text { variables }\end{array}$ & $\begin{array}{c}\text { MODEL } 1 \\
\text { Trade/Gdp ratio }\end{array}$ & $\begin{array}{c}\text { MODEL } 2 \\
\text { Import/Gdp ratio }\end{array}$ & $\begin{array}{c}\text { MODEL } 3 \\
\text { Export/Gdp ratio }\end{array}$ & $\begin{array}{c}\text { MODEL } 4 \\
\text { KOF/Gdp ratio }\end{array}$ \\
\hline Openness & $\begin{array}{l}0.257024 \\
(0.0185)^{* *}\end{array}$ & $\begin{array}{l}0.164827 \\
(0.2950)\end{array}$ & $\begin{array}{l}-0.028421 \\
(0.0896)^{*}\end{array}$ & $\begin{array}{l}-1.424565 \\
(0.0435)^{* *}\end{array}$ \\
\hline $\begin{array}{l}\text { Lag Inflation } \\
\text { Volatility }\end{array}$ & $\begin{array}{l}0.667062 \\
(0.0000)^{* *}\end{array}$ & $\begin{array}{l}-0.020067 \\
(0.8956)\end{array}$ & $\begin{array}{l}-0.022262 \\
(0.8847)\end{array}$ & $\begin{array}{l}-0.008615 \\
(0.9569)\end{array}$ \\
\hline Population Size & $\begin{array}{l}-1.4925 \\
(0.0234)^{* *}\end{array}$ & $\begin{array}{l}0.92506 \\
(0.7498)\end{array}$ & $\begin{array}{l}-1.8923 \\
(0.0377) * *\end{array}$ & $\begin{array}{l}0.49193 \\
(0.8812)\end{array}$ \\
\hline Lag Population Size & $\begin{array}{l}1.43958 \\
(0.6847)\end{array}$ & $\begin{array}{l}0.75510 \\
(0.7883)\end{array}$ & $\begin{array}{l}1.57666 \\
(0.5917)\end{array}$ & $\begin{array}{l}0.61904 \\
(0.8500)\end{array}$ \\
\hline Money Supply & $\begin{array}{l}-0.593721 \\
(0.0000)^{* *}\end{array}$ & $\begin{array}{l}0.032765 \\
(0.0963)^{*}\end{array}$ & $\begin{array}{l}0.058698 \\
(0.0216)^{*}\end{array}$ & $\begin{array}{l}-0.152677 \\
(0.0094)^{*}\end{array}$ \\
\hline $\begin{array}{l}\text { Government } \\
\text { Spending }\end{array}$ & $\begin{array}{l}0.254372 \\
(0.0003)^{* *}\end{array}$ & $\begin{array}{l}-0.138624 \\
(0.4398)\end{array}$ & $\begin{array}{r}(-0.114115) \\
(0.0438) * *\end{array}$ & $\begin{array}{l}0.201570 \\
(0.0153)^{* *}\end{array}$ \\
\hline $\begin{array}{l}\text { External Debt to } \\
\text { GDP Ratio }\end{array}$ & - & - & $\begin{array}{l}0.216171 \\
(0.0194)\end{array}$ & $\begin{array}{l}0.209769 \\
(0.3731)\end{array}$ \\
\hline R-Squared & 0.757956 & 0.189731 & 0.796194 & 0.741503 \\
\hline
\end{tabular}

Figures in brackets shows level of significance Note: * $10 \%$ level of significance ** $5 \%$ level of significance $* * * 1 \%$ significance

The lag selection is based on Akaike information criterion. According to Akaike information criterion for all models the AIC shows 2 to be maximum lag for estimation. The impact of one S.D shock of inflation volatility to itself is positive. The impact of one S.D shock to IEGCR ratio leads to negative response in inflation volatility. Response of inflation volatility to MS is positive. The impact of impact of one S.D shock to POP leads to no impact on inflation volatility. Response of inflation volatility to ERR is negative. The impact of one S.D shock of GS to inflation volatility is small but positive. The response of IV on EDGCR is positive. 


\section{Response of IV to Cholesky One S.D. Innovations}

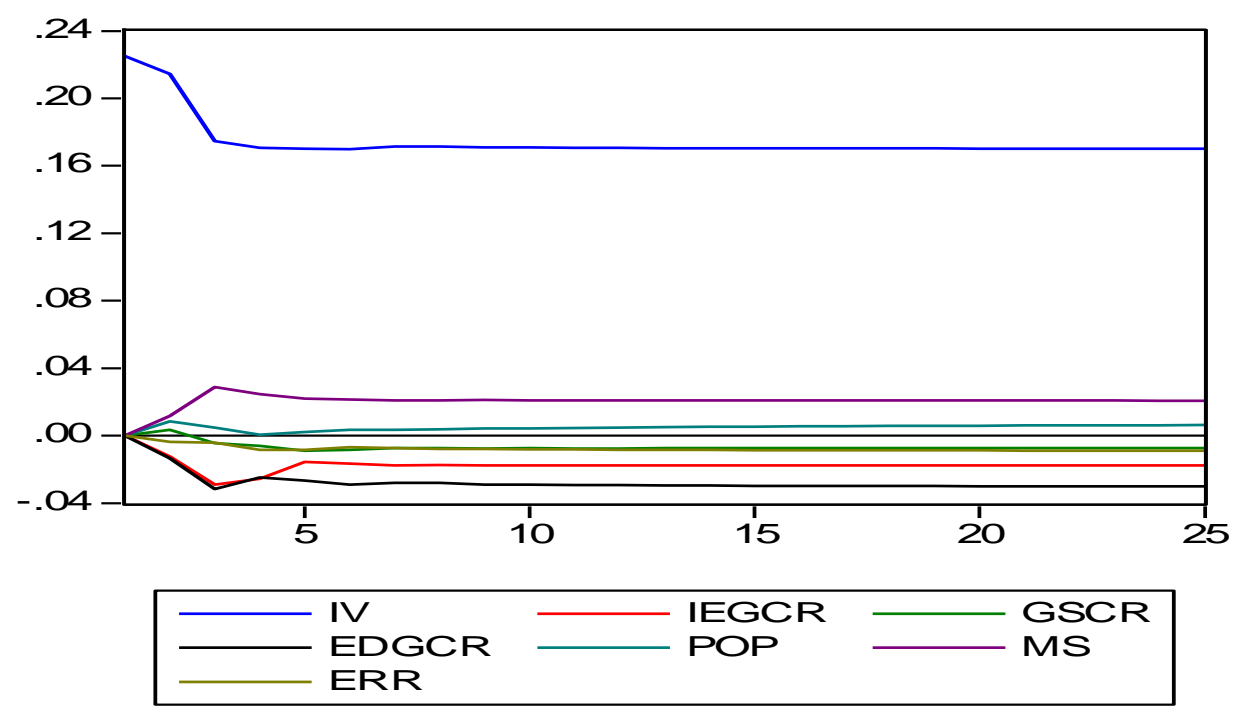

Figure 1

IV= inflation volatility level POP=Population size MS=Money supply LagIV=lag inflation volatility $\mathrm{GSCR}=$ Government size EDGCR=External debt $\mathrm{IEGCR}=$ Trade/GDP ratio ERR=Exchange Rate Regime

\section{Conclusions}

The study shows negative relation between inflation and openness when export is taken as proxy. The reason behind the relationship is that when we export goods, inflation is exported to imported country. Therefore the exported country does not get affected. When KOF/GDP ratio is taken the relation is negative. The reason is KOF index does not include only trade but along with include technological exchange, cultural exchange and more stable cordial relations among the trading countries. When import/ GDP and Trade/GDP ratio is taken as proxy than the relation is positive. The reason is with imports a country not only imports products but along with also import the prevailing inflation situation from the exported countries. Impulse Response function gives the following results. There exists a long run relationship between openness and inflation volatility. The effect of one standard deviation shock to ERR on inflation volatility appears in long run but no short run relation exists. There exist long run relationship between external debt and inflation volatility. Money supply has long run relation with inflation volatility.

\section{References}

Ajaz, T., Nain, M. Z., \& Kamaiah, B. (2016). Inflation and openness in India: an asymmetric approach. Macroeconomics and Finance in Emerging Market Economies, 9(2), 190-203.

Alfaro, L. (2005). Inflation, openness, and exchange-rate regimes. The quest for short run commitment, Journal of Development Economics, 77(1). 229-249.

Arellano, M., and Bond, S. (1991). Some tests of specification for panel data: Monte Carlo evidence and an application to employment equations. The review of economic studies, 58(2), 277-297.

Arellano, M., and Bover, O. (1995). Another look at the instrumental variable estimation of errorcomponents models. Journal of econometrics, 68(1), 29-51.

Ashraa, S. (2002). Inflation and openness: a study of selected developing economies. Indian Council for Research on International Economic Relations, 14(84), 100-135. 
Auer, R. A., and Mehrotra, A. (2014). Trade linkages and the globalization of inflation in Asia and the Pacific. Journal of International Money and Finance, 49(1), 129-151.

Bowdler, C., and Malik, A. (2017). Openness and inflation volatility: Panel data evidence. The North American Journal of Economics and Finance, 41, 63-86

Bowdler, Christopher, and Adeel Malik. "Openness and inflation volatility: Panel data evidence." The North American Journal of Economics and Finance 41 (2017): 57-69.

Darici, B. (2016). The effects of openness on inflation: Panel data estimates from selected developing countries. Investment Management and financial Innovations, 6(4):28-34

Dupor, B., and Li, R. (2015). The expected inflation channel of government spending in the postwar US. European Economic Review, 5(74), 36-56.

Evans, R. W. (2012). Is openness inflationary? Policy commitment and imperfect competition. Journal of Macroeconomics, 34(4), 1095-1110.

Jain, R., and Singh, J. B. (2009). Trade pattern in SAARC countries: Emerging trends and issues. Reserve Bank of India Occasional Papers, 30(3), 73-117.

Jin, J. C. (2006). Openness, growth, and inflation: Evidence from South Korea before the economic crisis. Journal of Asian Economics, 17(4), 738-757.

Lane, P. R. (1997). Inflation in Open Economies. Journal of International Economics, 42(3), 327-347.

Mukhtar, T. (2008). Does trade openness reduce inflation? Empirical evidence from Pakistan. The Lahore Journal of Economics, 15(2), 35-52.

Rizwanulhassan, M. (2015). Economic Integration: An Analysis of Major SAARC Countries. South Asian Studies, 30(1), 95-105.

Romer, D. (1991). Openness and inflation: theory and evidence. National Bureau of Economic Research, 8(4), 869-903.

Romer, D. (1998). A new assessment of openness and inflation: reply. The Quarterly Journal of Economics, 113(2), 649-652.

Samimi, A. J., Ghaderi, S., Hosseinzadeh, R., and Nademi, Y. (2012). Openness and inflation: New empirical panel data evidence. Economics Letters, 117(3), 573-577.

Terra, C. T. (1998). Openness and inflation: A new assessment. The Quarterly Journal of Economics, 113(2), 641-648.

Thomas, C. (2012). Trade Openness And Inflation: Panel Data Evidence For The Caribbean. The International Business \& Economics Research Journal, 11(5), 507-516. 